\title{
Working
}

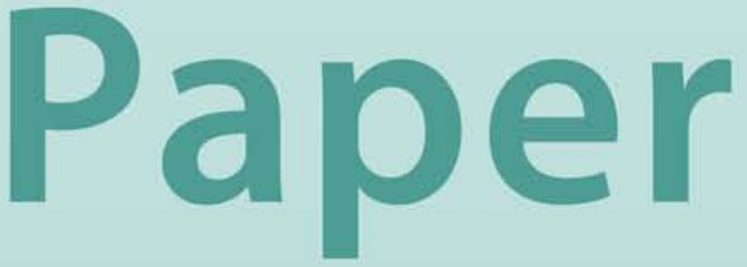




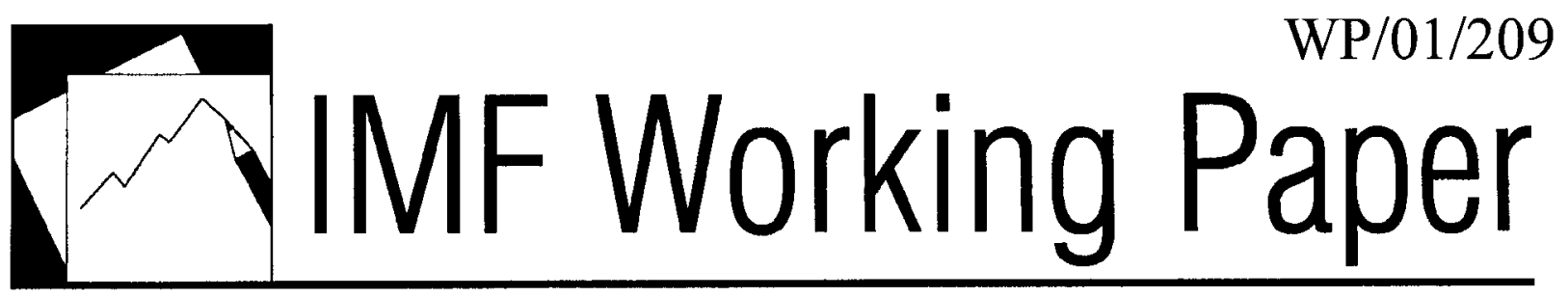

The Treatment of Nonperforming Loans in Macroeconomic Statistics

Adriaan M. Bloem and Cornelis N. Gorter 


\title{
IMF Working Paper
}

\author{
Statistics Department
}

\section{The Treatment of Nonperforming Loans in Macroeconomic Statistics}

\author{
Prepared by Adriaan M. Bloem and Cornelis N. Gorter ${ }^{1}$
}

December 2001

\begin{abstract}
The views expressed in this Working Paper are those of the author(s) and do not necessarily represent those of the IMF or IMF policy. Working Papers describe research in progress by the author(s) and are published to elicit comments and to further debate.
\end{abstract}

This paper seeks to promote discussion on the treatment of nonperforming loans in macroeconomic statistics. After reviewing current recommendations in international statistical manuals and the guidelines provided by some main banking and accounting institutions, the paper recommends that the information on nonperforming loans provided by macroeconomic statistics should be expanded. The paper concludes with a list of issues that deserve further study.

JEL Classification Numbers:C82, G34, M41

Keywords: General statistics, loan accounting, loan provisioning

Author’s E-Mail Address: abloem@imf.org, cgorter@imf.org

\footnotetext{
${ }^{1}$ Adriaan Bloem is Chief of the Real Sector Division of the IMF's Statistics Department. Cornelis Gorter is a senior economist in the same Division. The authors wish to thank the many colleagues in the Statistics Department that have provided comments on an earlier version of this paper. The responsibility for any errors remains with the authors. An earlier version of this paper was discussed by the Intersecretariat Working Group on National Accounts in its October 2001 meeting.
} 


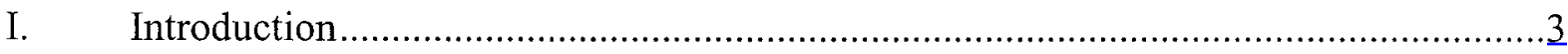

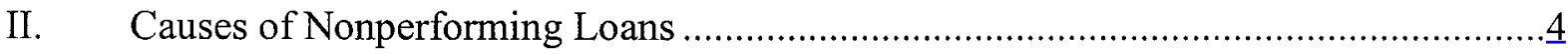

III. What are Nonperforming Loans?...................................................................

A. Criteria for Nonperforming Loans in the International Statistics Manuals .............6

B. Criteria for Nonperforming Loans Recommended by

Banking and Accounting Institutions...........................................................

IV. The Value of Loans.......................................................................................

A. The Value of Loans According to the International Statistics Manuals .................

B. Valuation of Loans Recommended by Banking and Accounting Institutions.........2

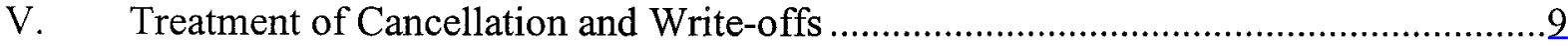

A. Treatment of Cancellation and Write-offs in the International Statistics Manuals 2

B. The Treatment of Cancellation and Write-offs Recommended by

Banking and Accounting Institutions.......................................................11

VI. Treatment of Interest on Nonperforming Loans .............................................13

A. Treatment of Interest on Nonperforming Loans in the International

Statistics Manuals .....................................................................................

B. Treatment of Interest on Nonperforming Loans Recommended by

Banking and Accounting Institutions...........................................................14

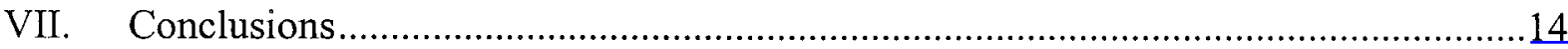

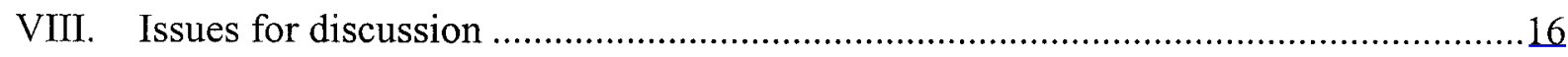




\section{INTRODUCTION}

1. The serious financial crises that have affected several countries since the mid 1990s have led to renewed interest in the question how macroeconomic statistics should account for nonperforming loans. ${ }^{2}$ The treatment in the System of National Accounts 1993 (1993 SNA) is based on important considerations that still are valid (for instance, the desirability of avoiding entries in the accounts for which there is no sound basis in observable transactions, the need for accounting practices to facilitate comparisons between different economic agents and countries, the need for valuation of loans to be consistent with the debtor's legal obligations, and the need for recommendations to be useful in measures of solvency). The result, however, is that in many cases the national accounts do not reflect the existence of nonperforming loans in either the flow accounts or balance sheets.

2. The other relevant international statistics manuals, namely the European System of Accounts 1995 (1995 ESA), the Balance of Payments Manual, fifth edition (BPM5), the Monetary and Financial Statistics Manual (MFSM), and the new Government Finance Statistics Manual (GFSM) are to a large extent consistent with the 1993 SNA. The MFSM, which was published in 2000, provides the most elaborated recommendations. ${ }^{3}$ (Throughout the paper we will refer to these manuals as "the international statistics manuals").

3. In a number of countries, the authorities have introduced regulations as relevant to their situation. These moves have prompted several international banking and accounting institutions, such as the Basel Committee on Banking Supervision (BCBS) and the International Accounting Standards Board (IASB), ${ }^{4}$ as well as influential private organizations, among which the Institute of International Finance (IIF), to develop sets of accounting criteria and recommendations for international reporting.

4. The BCBS guidelines are included in its Sound Practices for Loan Accounting and Disclosure, issued in 1999 (BCBS Sound Practices). This document contains a list of 26 sound practices in areas such as recognition and measurement of impairment, and the treatment on accrued interest. The IASB's views in the area are stated in International Accounting Standard 39: Financial Instruments: Recognition and Measurement (IAS 39), ${ }^{5}$ as revised by the IASB's

\footnotetext{
${ }^{2}$ Also dubbed impaired, nonaccrual, or bad loans.

${ }^{3}$ It should be mentioned, however, that the MFSM's treatment of provisions deviates from the other manuals.

${ }^{4}$ Previously the International Accounting Standards Committee (IASC).

${ }^{5}$ The IAS 39 was approved in December 1998 and is effective for accounting periods after January 1, 2001. See http://www.IASB.org.uk/frame/cen2 139.htm.
} 
Board in October 2000. The IIF's guidelines can be found in the Report of the Working Group on Loan Quality, issued in 1999 (IIF Report). ${ }^{6}$

5. The main issues of concern are (i) the criteria for identifying nonperforming loans, (ii) the value of such loans, (iii) the treatment of cancellations or write-offs on such loans, and (iv) the treatment of interest on these loans. These issues may require further clarification (or even adjustments) of the $1993 \mathrm{SNA}$, and this paper's purpose is to facilitate a discussion on the issue. In many cases, the issues raised regarding the treatment of loans apply equally to other debt instruments, such as trade credit and deposits.

6. Issues relating to non-performing loans may affect all sectors (in particular, if parallel issues with defaulting trade credits are also considered). The most serious impact, however, is on financial institutions such as commercial banks and mortgage financing institutions, which tend to own large loan portfolios. Indirectly, the customers of these financial intermediaries are also implicated: deposit holders, shareholders, and so forth.

7. This paper discusses first what nonperforming loans are and what could cause them. Subsequently, the main issues of concern (namely, the criteria for identifying nonperforming loans, the value of such loans, the treatment of cancellations or write-offs on such loans, and the treatment of interest on these loans) will be discussed, both from the perspective of the international manuals and the best practices recommended by various international banking and accounting institutions. Finally, some conclusions and issues for discussion will be presented.

\section{Causes of NonPerforming LoANS}

8. A more or less predictable level of nonperforming loans, though it may vary slightly from year to year, is caused by an inevitable number of wrong economic decisions by individuals and plain bad luck (inclement weather, unexpected price changes for certain products, etc.). Under such circumstances, the holders of loans can make an allowance for a normal share of nonperformance in the form of bad loan provisions, or they may spread the risk by taking out insurance. Enterprises may well be able to pass a large portion of these costs to customers in the form of higher prices. For instance, the interest margin applied by financial institutions will include a premium for the risk of nonperformance on granted loans.

9. The amounts involved in nonperforming loans may rise considerably as a result of less predictable incidents, such as when the costs of fuel, prices of key export products, foreign exchange rates, or interest rates change abruptly. A similar effect may be caused by the sudden failure of a major company in an overly optimistic financial market (in this context the term 'irrational exuberance' has been used). If the resulting loss of confidence begins to snowball toward a crisis, at least three effects tend to further aggravate the situation:

\footnotetext{
${ }^{6}$ Report of the Working Group on Loan Quality, Institute of International Finance, Inc. (July 1999). This report is available on the IIF's Internet site http://www.iif.com/.
} 
- A fall in the prices of loan collaterals (often real estate) may cause more loans to become classified as doubtful;

- Large bad loan portfolios will affect the ability of banks to provide credit, and the resulting liquidity crunch may suffocate otherwise good creditors;

- Depositors and foreign investors may start a run on the banks, pushing them into liquidity problems.

10. The chances for the financial sector to derail are usually considered to be much higher under conditions of deficient bank management, poor supervision, overoptimistic assessments of creditworthiness during boom economies, and moral hazard that results from (too) generous government guarantees or the expectation of assured bailouts. Large exposure to international financial market can also complicate matters considerably.

11. Major banking crises are common, ${ }^{7}$ and they may be very costly for the taxpayer. The 1987 savings and loan crisis in the U.S.A. and the bank crises in the Nordic countries a few years later necessitated the use of substantial amounts of public funds. The overall costs involved in 1994 Mexican crisis, the 1995 Argentine crisis, and the recent difficulties in the Japanese financial system are estimated to be even higher; the public funds used to address the banking crisis in Japan up till end 2001 amounted to some 5 percent of GDP. ${ }^{8}$ Particularly costly tend to be guarantees provided by the government in the form of blanket deposit insurance. ${ }^{9}$ An idea of magnitude emerges also from the estimate that realized losses during the Asian crisis amounted to 20 percent of total bank loans in Indonesia, and to 27 percent in Thailand. ${ }^{10}$

\footnotetext{
${ }^{7}$ See, for instance, Demiguc-Kunt, A. and Enrica Detragiache, The Determinants of Banking Crises in Developing and Developed Countries, (IMF Staff Papers, March 1998), table 1; and Lindgren, Carl-Johan et al, Financial Sector Crisis and Restructuring, Lessons from Asia, (IMF Occasional Paper 188, 1999).

${ }^{8}$ Japan: Economic and Policy Developments (IMF Country Report No 1/221, December 2001), page 76.

${ }^{9}$ Blanket guarantees and their removal in systemic crises are discussed in Garcia, Gillian G.H., Deposit Insurance, Actual and Good Practices, (IMF Occasional Paper 197, 2000).

${ }^{10}$ Kong Yam Tan, Regional Trading Arrangements in the Asia-Pacific Region: Strategic Options for a Weakened Asean. (http://www.brandeis.edu/glbal/research/tan.htm, undated), table 2.
} 


\section{What ARE NONPERFORMING LOANS?}

\section{A. Criteria for Nonperforming Loans in the International Statistics Manuals}

12. The $1993 S N A$ does not provide criteria to decide what should be classified as nonperforming loans, and other international statistics manuals are also silent on the subject. Concerning nonperforming loans, the bottom line in the international manuals seems to be that loans are good unless there is absolute certainty that a loan is not going to be repaid under existing arrangements. Thus, loans remain on the balance sheets until a debt cancellation, writeoff, or write-down ${ }^{11}$ has taken place. A different position is taken by the MFSM. Although the $M F S M$ also records loans without adjustment for expected losses (paragraph 40), provisions for loan losses enter under "Other Accounts Payable" (paragraph 179).

13. The $1993 S N A$ does not provide strict criteria to decide at which state exactly a nonperforming loan should be regarded as not existing anymore. In practice, therefore, one must rely on administrative or commercial accounting conventions as prevailing in a country or internationally recommended.

\section{B. Criteria for Nonperforming Loans Recommended by Banking and Accounting Institutions}

14. The extent to which authorities have been involved in developing criteria to distinguish between "good" and "bad" loans differs substantially between countries and, as mentioned, banking and accounting institutions have come in to provide guidance on this issue. Some countries use quantitative criteria (e.g., number of days of overdue scheduled payments), while other countries exclusively rely on qualitative norms (such as availability of information about the client's financial status, management judgment about future payments). Some countries (including Germany and the U.K.) do not give standard criteria at all. ${ }^{12}$ Furthermore, it cannot be said that a loan is either 'good' or 'bad' as there is a sliding scale in credit quality from riskfree loans to those that do not give any hope for recovery.

15. To improve the ability to make comparisons between banks across countries, the IIF Report proposes that, for world-wide external reporting, the following categories be used:

\footnotetext{
${ }^{11}$ See 1993 SNA 11.23 for a discussion of these alternatives.

${ }^{12}$ An overview of country practices can be found in Appendix 1 of Loan Review, Provisioning, and Macroeconomic Linkages, IMF Working Paper WP/00/195, December 2000.
} 
- Standard: Credit is sound and all principal and interest payments are current. Repayment difficulties are not foreseen under current circumstances and full repayment is expected.

- Watch: Asset subject to conditions that, if left uncorrected, could raise concerns about full repayment. These require more than normal attention by credit officers.

- Substandard: Full repayment is in doubt due to inadequate protection (e.g., obligor net worth or collateral) and/or interest or principal or both are more than 90 days overdue. These assets show underlying, well-defined weaknesses that could lead to probable loss if not corrected and thus risk becoming impaired assets.

- Doubtful: Assets for which collection/liquidation in full is determined by bank management to be improbable due to current conditions and/or interest or principal or both are overdue more than 180 days. Assets in this category are considered impaired but are not yet considered total losses because some pending factors may strengthen the asset's quality (merger, new financing, or capital injection).

- Loss: An asset is downgraded to Loss when management considers the facility to be virtually uncollectible and/or when interest or principal or both are overdue more than one year.

16. This classification may indicate that there are two cases that have to be addressed, (i) loans that are a complete loss, and (ii) loans whose quality is significantly impaired (substandard or doubtful) and for which, taken as a group, experience shows that a notable portion of the future interest and/or installment payments will never be made.

17. According to the IASB's $I A S 39$, a financial asset is impaired if its carrying amount is greater than its estimated recoverable amount (see IAS 39, paragraph 109).

\section{The Value of Loans}

\section{A. The Value of Loans According to the International Statistics Manuals}

18. In general, according to the international statistics manuals the value of loans is not affected by perceived impairment. The 1993 SNA and the other international manuals do not recognize impairment of unsecured loans until they fail or are renegotiated. Thus, until the actual event takes place that confirms impairment - either through cancellation, write-offs, or write-downs - from the perspective of the international manuals there is no reason to revalue loans. The monetary value of cash, deposits, loans, advances, credits, etc. remains constant over time (except when denoted in foreign currency). The "price" of such an asset is always unity, and the nominal holding gains on such assets are always zero (1993 SNA, paragraph 12.107). 
19. The consistency of the national accounts system requires that financial assets should be assigned the same value whether they appear as assets or liabilities (1993 SNA, paragraph 13.64). As will be discussed below, this consistency requirement is not maintained in some of the guidelines provided by the various banking and accounting institutions.

20. It should be noted that the $1993 S N A$ treatment of loans is markedly different from loans that have become negotiable de facto, which are classified as securities other than loans (1993 SNA 11.75). Securities that are regularly traded should be valued at current market price. $^{13}$

21. Thus, the 1993 SNA's treatment largely rests on the criterion of "marketability." This criterion is somewhat arbitrary because, often, loans that are not traded on a regular basis can, nevertheless, be sold. ${ }^{14}$

22. According to the $M F S M$, the entire loan portfolio, except for loans that have become negotiable in secondary markets, should be valued at the outstanding principal amounts plus any accrued interest. ${ }^{15}$ As already indicated in section III, the valuation is not to be adjusted for expected losses. The value of a loan portfolio should be adjusted only when (1) loans are actually written off as uncollectible or (2) when the outstanding amount of the loan has been reduced through formal debt reorganization (MFSM paragraphs 206, 207, 238-9, 390).

23. However, as already indicated above, the MFSM records provisions for loan losses under "Other Accounts Payable." For supervisory purposes and macroeconomic analysis, the $M F S M$ also recommends that memorandum items show (1) interest arrears on loans and (2) expected loan losses for use in obtaining alternative valuations of loan portfolios (MFSM paragraph 390 and Box 7.1).

\footnotetext{
${ }^{13}$ If market prices for securities are not available, they should be valued at face value plus any accrued but not yet paid interest (1993 SNA paragraphs 13.64, and 13.67-9). The text of the $1993 S N A$ is not fully clear in this respect. We presume that the valuation rules given in paragraph 13.67 with respect to short-term bonds for which no market prices are available also apply to long-term securities other than shares.

${ }^{14}$ The August 2001 version of the draft External Debt Statistics: Guide for Compilers and Users (EDSG) paragraph 135 undertakes to add specificity where it reads: "Given the significance of reclassification, there needs to be evidence of secondary market trading before a debt instrument is reclassified from a loan to a security. Evidence of trading on secondary markets would include the existence of market makers and bid-offer spreads for the debt instruments." (The text of the draft EDSG is available at http://www.imf.org/external/np/sta/ed/guide.htm.)

${ }^{15}$ The MFSM uses the term 'book value.'
} 


\section{B. Valuation of Loans Recommended by Banking and Accounting Institutions}

24. The $I A S 39$ proposes the following method to recognize and assess the value of the impairment or uncollectibility of loans (IAS 39, paragraph 111):

- Loans, receivables originated by the enterprise and not held for trading, and debt securities that the enterprise intends and is able to hold to maturity should be carried in the balance sheet at amortized acquisition cost, less reductions for impairment or uncollectibility.

- Other financial assets are recorded at fair value.

25. In IAS 39, the value of loans on the liabilities side of the balance sheet is not influenced by considerations of impairment or changes in the general interest rate. However, such different valuation of financial instruments depending on whether they are assets or liabilities is not be acceptable in the national accounts because it would imply inconsistencies between the debtor's and creditor's accounts.

26. According to $I A S 39$, valuation of debt instruments on the asset side depends on whether or not there is an intention for trading. While this make sense form the perspective of an individual enterprise's accounts, intentions are difficult to apply directly in the national accounts.

\section{TREATMENT OF CANCELLATION AND WRITE-OFFS}

\section{A. Treatment of Cancellation and Write-offs in the International Statistics Manuals}

27. As mentioned, the 1993 SNA and the other international statistics manuals do not recognize impairment to loans, except for (i) cancellation of debt by mutual agreement, or (ii) writing off debt. Cancellation of debt by mutual agreement between the creditor and the debtor (debt forgiveness) is treated as a capital transfer. Writing off of debt, that is, the recognition by a creditor that the financial claim can no longer be collected due to bankruptcy or other factors is not a transaction between institutional units and is recorded in the other changes in the volume of assets account of the creditor and the debtor. Unilateral repudiation of debt by a debtor is neither a transaction to be recorded in the transaction accounts of the System, nor an other change in assets (1993 SNA paragraphs $10.140,11.23,12.51,12.52)$.

28. If loans are rescheduled, the new loans' nominal value ${ }^{16}$ will be the basis of valuation, and the differences with the nominal value of the original loan will be recorded as a holding gain or loss (1993 SNA paragraph 14.51).

\footnotetext{
${ }^{16}$ Paragraph 14.51 of the 1993 SNA defines 'nominal value' as the amount of principal that the debtor is contractually obliged to repay the creditor when the loan matures. It should be noted that the draft $E D S G$ calls this
} 
29. According to the 1993 SNA, write-downs that reflect the actual market values of financial assets should be accounted for in the revaluation accounts of the System.

Write-downs or write-offs that are imposed solely to meet regulatory or supervisory requirements and do not reflect the actual market values of those financial assets should not be recorded (1993 SNA paragraph 11.23). An exchange of discounted loans for equity is valued at the (lesser) value of the equity, with the difference between the nominal value of the loan and the value of the equity treated as a holding gain/loss (1993 SNA paragraph 14.51). Changes in claims resulting from debt assumption or rescheduling are considered new contractual arrangements (1993 SNA paragraph 11.23). Provisions for bad debt are treated as bookkeeping entries that are internal to the enterprise and do not appear anywhere in the system (1993 SNA paragraph 10.140).

30. Loans that are subject to discounts quoted in secondary markets should, in principle, be valued on the basis of such quotes. However, the basis of valuation of the liabilities on the debtor side is nominal value. The use of market value on the creditor side and nominal value on the debtor side results in an asymmetry between debtor and creditor positions. In order to deal with that asymmetry, if feasible, creditors should provide supplementary data on nominal values of discounted loans, and debtors should provide such data on market value (1993 SNA paragraph 14.51). ${ }^{17}$

31. In practice, the losses that the $1993 S N A$ records as other changes in volume are mostly the result of catastrophic circumstances (if losses occur in the normal course of business, these are to be recorded as negative output). It could be argued that defaulting on debts is a normal risk of business in banking, and from that point of view it is difficult to see why the resulting loss should be treated as a catastrophic loss. As, furthermore, it is very likely that the rates financial intermediaries set include a risk premium, the 1993 SNA may well cause recording of overstated values for output and operating surplus of banks and other financial intermediaries.

32. According to the MFSM, debt rescheduling refers to the formal deferment of debt service (i.e., interest and/or principal payments) and the creation of a new repayment schedule, usually including a new maturity, for the debt obligation (MFSM paragraph 209) Debt refinancing refers to the conversion of a debt obligation-a loan or a security other than shares-into a new debt instrument (MFSM paragraph 210). Debt assumption is a special form of debt refinancing, involving three parties - the creditor, the original debtor, and a new debtor who assumes the debt obligation. A debt assumption involves two simultaneous transactions; the first transaction cancels the original debtor's obligation (classified as a capital transfer), and the second transaction creates a new debt contract between the creditor and the new debtor, or assumer. Any write-down of asset value by the creditor is recorded in the revaluation accounts (MFSM paragraph 211). Debt swaps refer to the exchange of debt for a new debt contract

\footnotetext{
'face value.' In the draft $E D S G$, 'nominal value' is equal to the required future payments of principal and interest on current liabilities discounted by the existing contractual rate of interest.

${ }^{17}$ It may well be questioned whether 1993 SNA paragraph 14.51 fits within the overall concept of the System.
} 
(i.e., debt-debt swap) or the exchange of debt for equity (i.e., debt-equity swap). Any holding loss from writing down the value of the original debt is recorded in the revaluation account (MFSM paragraph 212). ${ }^{18}$

\section{B. The Treatment of Cancellation and Write-offs Recommended by Banking and Accounting Institutions}

33. In general, there are three ways of dealing with impaired loans (assets) in commercial accounting:

- Expense the impairment against the current period's income, and make a counter-entry on the liabilities side of the enterprise's balance sheet (sometimes referred to as making a provision). ${ }^{19}$ This procedure reduces the amount of profits for the period that are transferred to retained earning in the capital account ${ }^{20}$. At the moment the loan is actually lost, the full value of the loan is taken out from the asset items on the balance sheet and the item loan provisions under the liability items is reduced with the amounts provisioned for that loan.

- Do not expense against income. Instead, make an appropriation from retained earnings to a separate component of capital called 'reserves.' This leaves the enterprise's capital unaffected until the moment the loss actually materializes, at which time it is expensed for its full amount.

- Expense the impairment and diminish the net value of the loan portfolio on the asset side of the balance sheet. This reduces capital in the current period. This procedure may be seen as equivalent to the case described under the first bullet, but the provisions are netted out against holdings of loans on the assets side rather than shown as a separate item on the liabilities side of the balance sheet. No specific entries are made at the moment the loss actually materializes.

34. The IAS approved the following standards in respect of recognition and measurement of the financial instruments under discussion here:

- Revaluations are treated as a profit or loss for the period.

\footnotetext{
${ }^{18}$ An extensive discussion on debt reorganization is included in Chapter Seven of the earlier indicated draft $E D S G$.

${ }^{19}$ Provisions can be general (for latent, not yet identified losses) or specific (for identified impairment to individual loans or narrowly defined categories of loans).

${ }^{20}$ In commercial accounting, the capital account is the analogue of the item 'shares and other equity' in the national accounts.
} 
- When impairment occurs, the carrying amount of the asset should be reduced to the estimated recoverable amount either directly or through the use of an allowance account. The loss should be included in net profit or loss for the period (IAS 39, paragraph 113). This procedure is reversed if the impairment deceases in a subsequent period (IAS 39, paragraph 114).

35. The BCBS's Sound Practices contains among other things the following guidelines that apply specifically to banks:

- A bank should remove a loan from its balance sheet when, and only when, the bank loses control of the contractual rights that comprise the loan. The loan should be measured, initially, at cost (sound practices 5 and 6).

- A bank should identify and recognize impairment in a loan or a collectively assessed group of loans when it is probable that the bank will not be able to collect, or there is no longer reasonable assurance that the bank will collect, all amounts due according to the contractual terms of the loan agreement (sound practice 7).

- Impairment should be recognized by reducing the carrying amount of the loan(s) through an allowance or write-off and charging the income statement in the period in which the impairment occurs. An impaired loan is measured at its estimated recoverable amount. The recoverable amount could be (i) the net present value of expected future returns, (ii) the fair value of the collateral, or (iii) an observable market price (sound practices 7 and 8 ).

- When a loan is identified as impaired, a bank should cease accruing interest in accordance with the terms of the (original) contract (sound practice 11). ${ }^{21}$

- The BCBS guidelines consider only debt held as assets. All impairments are charged against income of the current accounting period and the value of the loan is diminished, which is in agreement with the third method indicated in paragraph 33.

\footnotetext{
${ }^{21}$ The report notes that in some countries, banks as a result of regulations must accrue interest on impaired loans with the original terms. In that case, the report recommends eliminating the effect by making a corresponding specific allowance.
} 


\section{TREATMENT OF INTEREST ON NONPERFORMING LOANS}

\section{A. Treatment of Interest on Nonperforming Loans in the International Statistics Manuals}

36. There are no guidelines in the $1993 S N A$, or in the other international statistics manuals, on whether impaired loans continue to accrue interest. From the fact that the $1993 S N A$ does not acknowledge impaired loans before they fail or are renegotiated, it can be inferred that interest should be recorded in the accounts as accrued as long as the loan remains in the books.

Accordingly, even if the debtor fails to make the contractual payments, the financial accounts should show a gradual increase of the creditor's claim. ${ }^{22}$ This interpretation is supported by the $1993 S N A$ 's treatment of provisions or revaluations (see section $\mathrm{V}$ of this paper).

37. The MFSM is more explicit on this issue, and states that interest that is overdue for payment is included in the loan data on the sectoral balance sheets. As already indicated above, data on both expected loan losses and interest arrears should be shown as memorandum items (MFSM paragraph 205).

38. One important consequence of recording unpaid interest on impaired loans is that the financial intermediary services indirectly measured (FISIM) as recorded in the national accounts (either compiled following the interest margin approach or the reference rate approach) can be deemed as overstated if in reality imputed interest on impaired loans is never paid. ${ }^{23,24}$

39. However, it can also be argued that the financial service for which FISIM was recorded has been delivered, no matter whether it is eventually paid for or not. Seen from this angle, unpaid FISIM should be recorded as output, and treated in the same way as output of other industries that is not paid for (see section V on the 1993 SNA treatment of debt cancellation and write-off).

40. It has been argued that interest should not be recorded on loans if that interest is never likely to be collected because accrual-based accounting only makes sense when the amounts are ultimately paid. Acceptance of this argument brings forward in time the loss on interest payments (and probably repayments of the principal) that otherwise would be accounted for as

\footnotetext{
22 An interesting case where the 1993 SNA allows leaving claims unrecorded concerns taxes that, although assessed, are not actually paid (see 1993 SNA, paragraph 8.50).

23 An probable losses on account of nonperforming loans. This argument presumes that banks are able to pass the risks of loans on to their customers (cf. paragraph 8 of this paper).

${ }^{24}$ Overstatement or understatement of FISIM would not lead to changes in the estimate of GDP according to the 1968 SNA. However, in the 1993 SNA such changes are possible, depending on the type of use made of the FISIM and the type of institutional unit that consumes FISIM (Annex III in the 1993 SNA provides a full discussion of these issues).
} 
a write-off. Supervisory institutions may instruct banks to act according to these lines. However, this approach is problematic in the framework of the national accounts for both practical and theoretical reasons. It is difficult to find objective criteria for adequately identifying when exactly the likelihood of nonpayment is sufficient to stop the accrual of interest, although by convention rules could be adopted on number of days payments are overdue or the number of installments missed. Furthermore, doubts about ultimate interest receivables do not change the legal obligation of the debtor to pay. By force of the rule of symmetry, which is essential to national accounting, this obligation should be reflected in the debtor's and the creditor's balance sheets at exactly the same value.

\section{B. Treatment of Interest on Nonperforming Loans Recommended by Banking and Accounting Institutions}

41. Concerning the recognition of income on impaired loans, the $I A S 39$ states: After a financial asset has been written down to its estimated recoverable amount, recognized interest income is thereafter based on the original effective interest rate (see IAS 39, paragraph 116 in combination with 111).

42. The Sound Practices of the Basel Committee on Banking Supervision (BCBS) considers only debt held as assets, and recommends that a bank should cease accruing interest in accordance with the terms of the contract when a loan is identified as impaired (sound practice 11). Although the general thrust of this recommendation is clear, some questions remain on the exact implications. For instance, sound practice 10 states that interest on an unimpaired loan should accrue using the effective interest rate method (the rate of return implicit in the contractual payments of the loan and the costs to acquire the loan). Practice 11's reference to contractual interest instead of effective interest is rather cryptic, therefore.

43. It should be noted that the BCBS has recently issued a proposal to replace the 1998 Basel Capital Accord. The proposal defines capital requirements for commercial banks differentiating between credit risk exposure by a few types of counterparty and categories of asset. ${ }^{25}$ The BCBS has recognized that progress in defining the treatment of loan losses is critically important to the Accord, and has indicated that it will work with the IASB in this regard. Many of the public comments on the draft Accord have stressed the importance of clarifying or standardizing the treatment of losses. The new Accord will likely reflect seminal work in a number of areas, including loss recognition and provisioning.

\section{Conclusions}

44. The discussion in the previous sections make clear that there are important differences between the national accounts - and other macroeconomic statistics - and commercial bookkeeping. First, in the national accounts financial instruments are recorded according to the

${ }^{25}$ See press release http:/www his.org/press/p010116htm of $1 / 18 / 01$. 
same principles, whether classified as an asset or a liability. ${ }^{26}$ In contrast to commercial bookkeeping, provisions for bad debt (loans or other debt instruments) are not recorded at all in the System. The 1993 SNA does not allow recording of provisions, and the national accounts reflect price changes that are caused by impairment of traded debt instruments as holding gains or losses. For debt instruments that are not traded, however, the 1993 SNA excludes any change in prices by definition. This leaves as the only option to record the impairment (once it materializes) as an 'other change in the volume of assets.'

45. Because there is no objective way to assess the extent of impairment to nontraded instruments, the $1993 S N A$ appears to have adopted an all-or-nothing approach: the loss of the full claim is entered if and when the creditor recognizes that the claim can no longer be collected. In no case is an entry made in the income accounts, which might be criticized because, as noted above, to some extent the occurrence of bad debt is a normal cost of doing business and not showing this cost leads to an overstatement of output and operating surplus. The main problem for the 1993 SNA probably is the positive mirror entry that would have to be made in the accounts of the defaulting debtor. ${ }^{27}$ A further important disadvantage of the noncommittal position taken by the 1993 SNA is that no information at all is provided about impaired, but not yet lost, loans. Arguably, this reduces the analytical value of the national accounts.

46. In view of the conclusions of the above paragraphs, and to improve the link between micro and macro economic accounting, this paper recommends that the 1993 SNA should provide for memorandum items to the accounts, specifying the value of provisions that should be made in respect of nonperforming loans. A distinction should thereby be made between provisions on the face value and the accrued interest. It is recognized that conceptual work is needed to implement this recommendation. However, generally accepted commercial practices should serve as guidelines.

47. The fact that partial impairment to tradable debt instruments is treated as a price effect, but the complete loss of the financial instrument is classified as a volume effect is not elegant from a theoretical point of view. Indeed, any impairment would seem to be in essence a change in volume (quality), although it is difficult in practice to isolate this volume change within the overall value change of a traded financial instrument.

48. The distinction the 1993 SNA makes between loans that are marketable and loans that are not seems somewhat artificial, and a rather shaky basis to underpin different valuation rules. The emergence of financial derivatives often enables the establishment of proxy market values

\footnotetext{
${ }^{26}$ Although the discussion in 1993 SNA, paragraph 14.51 is regrettably unclear on this issue, not distinguishing more explicitly between principles and practical estimation issues. The same wording can be found in the Balance of Payments Manual, fifth edition, paragraph 471.

${ }^{27}$ In combination with the circumstance that the $S N A$ does not define any balancing items that are composed of both transactions and other flows.
} 
for nontraded instruments. This paper recommends that, in the long run, the $1993 S N A$ valuation principles for financial instruments based on the distinction market versus non-market should be revisited.

49. The effect on FISIM of continuing the accrual of interest on impaired loans can be sizeable, and could be deemed misleading. However, a case can also be made that the financial service has de facto been delivered, even it turns out that it was eventually not paid for.

50. Even recognizing that an overall statistical system has to answer specific conditions such as consistency between creditors' and debtors' accounts, the 1993 SNA seems at odds with the international best practices as recommended by the IIF, the IASB, and the BCBS (although these do not seem fully consistent either).

51. For all these reasons, it should be considered whether adjustments are needed to bring the international manuals in line with the recommended best practices. However, it should also be recognized that it might still be too early to say what are the new consensus best practices. It seems that statistical experience and standards and the economic principles on which they are based could still constructively influence commercial accounting or supervisory standards. Harmonization should thus be a two-way exchange of ideas rather than a simple adoption by the statistical manuals of what non-statisticians choose to decide. It is advisable that a strategy be developed to promote and monitor this process.

\section{ISSUES FOR DISCUSSION}

52. This paper's review of existing guidelines indicates that macroeconomic statistics should better account for nonperforming loans. The Intersecretariat Working Group on National Accounts (ISWGNA) ${ }^{28}$ in its October 2001 meeting endorsed this view and asked the International Monetary Fund to set up an Electronic Discussion Group (EDG) to come to more concrete proposals in this domain. Some of the issues that the EDG may want to address are the following:

- What should be the definition of a bad or nonperforming loan? Should there be different definitions for different circumstances? Are deposits and trade credit to be treated in the same way as loans when they become impaired?

\footnotetext{
${ }^{28}$ The ISWGNA was created in 1983 by the UN Statistical Commission to coordinate the revision process of the SNA. Since the publication of the 1993 SNA, the ISWGNA supports the implementation of the new recommendations, resolves conceptual and practical problems, and has an important role in the further development of national and satellite accounting. The Group comprises respresentatives of the European Union, the International Monetary Fund, the Organisation for Economic Co-operation and Development, the UN Statistical Division, and the World Bank.
} 
- Which of the following options is most appropriate in the context of the national accounts and related macroeconomic statistics concerning the valuation of loans: (i) continue the present 1993 SNA conventions, (ii) change the loan valuation rules to reflect provisions for nonperformance, (iii) continue the current approach, but show provisions for nonperforming loans as memoranda items.

- Should the international statistics manuals contain more criteria on when exactly a loan is non-recoverable and should be completely written off?

- Should the international statistics manuals be changed to allow price fluctuations in loans that are expressed in domestic currency? How should this be implemented in practice? Are there better ways to improve the informative value of the national accounts in tracking impaired loans?

- Would it be more consistent to treat the write-off of bad loans as price changes rather than other changes in volume (taking into account that quality changes in traded financial instruments cannot be distinguished separately)?

- Should the national accounts cease to record interest accrual on impaired loans? Are financial institutions to be treated different in this respect from other holders of credit instruments?

- Should the international statistics manuals define an income concept that includes expected or actual losses on financial claims? Should a difference be made for that purpose between 'normal' losses and 'catastrophic' losses? 